\title{
織物の温度伝達特性の一測定法
}

\author{
信州大学瀻維学部 鳥羽栄治・青沼 務・讯路雅夫
}

\section{A MEASURING METHOD OF TEMPERATURE TRANSFER CHARACTERISTICS OF WOVEN FABRICS}

\section{By Eiji Toba, Tsutomu Aonuma and Masao Sawaji}

(The Faculty of Textile Science and Technology. Shinshu University, Ueda City)

This paper describes an attempt to detect the irregular temperature fluctuation (output signal) right after passing through woven fabrics by the use of a special CA thermopile having high sensitivity and fine frequency characteristics. By finding the ratios of changes in amplitude and phase of inputoutput signals, we have tried to measure temperature transfer characteristics of woven fabrics in case of the dynamic state.

The main results obtained are as follows.

1) The temperature transfer characteristics of woven fabrics are closely related to the degree of the air permeability; the higher the degree is, the better temperature transfer characteristics are.

2) $\{G(s)\}$, the temperature transfer function of woven fabrics, can be expressed as $G(s)=$ $e^{-L_{s}} /\left(1+T_{s}\right)$. Thus, the temperature transfer characteristics of woven fabrics are evaluated by calculating the value of $T$ and $L$.

(Received August 24, 1978)

\section{1.はじめに}

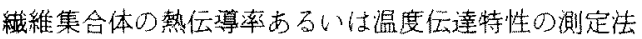
については，従来から多くの研究 ${ }^{1)}$ が恬されている。し かし，これらの測定法はいずれも静的な場合での測定で あり，気体の流れを考虑した動的な場合での温度伝達特 性の測定については，動特性の優れていてかつ高感度の 温度せンサーの開発がネックとなっており，研究が余り 進んでいない。本研究は玲却速度法 ${ }^{27}$ を应張して，入力 信号として人為的な温度ゆらぎ信号》を内管内の気体の 流㧈に重䁌させ，織物面に連続的に印加し，織物面通過 直後の温度ゆら光信号 (出力信号) 在高感度速応答型 CA

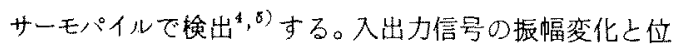
相变化の度合を求めることにより，動的な場合の織物の 温度伝澾特性の測定 ${ }^{\natural)}$ を試み，また，乙れを支配する因 子について考察した。

\section{2. 実験装置及び方法}

困 1 亿実駼装䈯の概要在示す。管内径 $40 \mathrm{~mm}$ の硬質 塩化ビ二ル管で配管した管路系に变速ブロワーで空気在 送風する。送り出された空気は電熱式加熱器を通って加 熱され，不規則な温度中らぎが印加され，気体の流机に 乘って下流に運げれる。この温度ゆらさ信号を管路内代 垂直にセットした織物面に印加し，織物面前㣪の温度ゆ らき信号 $\left\{\theta_{1}(t), \theta_{2}(t)\right\}$ を特性のそ万った高感度速応答 型 $\mathrm{CA}$ サーモパイル TP 2 と $\mathrm{TP}_{2}$ で検出する。こてで， $\theta_{1}(t)$ と $\theta_{2}(t)$ は線形の因果的関係にあるので, $\theta_{1}(t)$ の自己相関関数 $\phi_{\theta_{1}-\theta_{1}}(\tau)\left\llcorner\theta_{1}(t) と \theta_{2}(t) の\right.$ 相互相関 関数 $\phi_{\theta_{1}-\theta_{2}}(\tau)$ 在求め, 更にこ机らをフーリ土变換し， 自己パワースペクトル $\emptyset_{\theta_{1}-\theta_{1}}(\omega)$ ，相互パワースペクトル

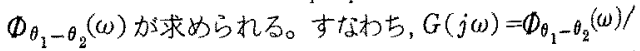
$\Phi_{\theta_{1}-\theta_{1}}(\omega)$ の值を計算すると， $\theta_{1}(t)$ が織物を通り技外 


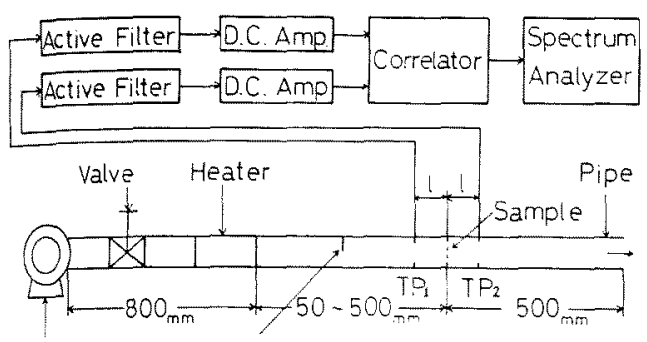

Variable speed Hotwire Anemometer Slower

Fig. 1 Schematic arrangement

て $\theta_{2}(t)$ 上なった場合，周波数 $\omega$ に対する掁幅变化上位 相变化の度合老求めるここができる。しれらの関係をボ

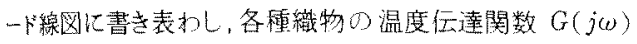
古推定する。

な步，本害験は大気温度(空混 $20^{\circ} \mathrm{C}$ )，相対漣度 $60 \%$ 上一定条件の古して，管内平均溻度 $\bar{\theta}=30^{\circ} \mathrm{C}$ ，管内平均 流速 $V=1 \sim 5 \mathrm{~m} / \mathrm{s}$ (Red. 数 $2 \times 10^{3} \sim 1.3 \times 10^{4}$ ) 0 範媅で 行っな。Vの測定は白金線熱線風速計を使用し、平均 流速加実験中に変動しないし亡在確認した。織物面上検 出器 TP 接加熱用七一タとして，サーモコア，クスヒータ(フィ

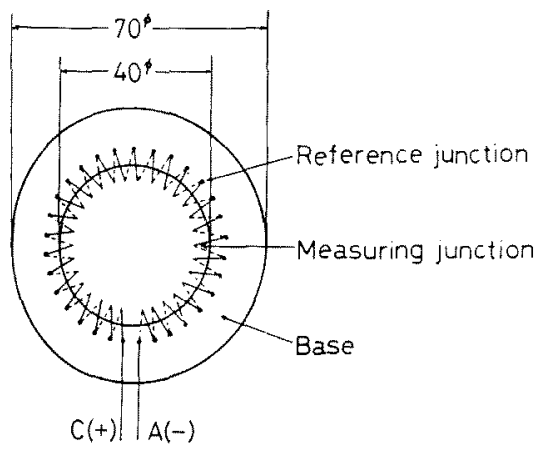

Fig. 2 Construction of thermopile.
リップス製，線径 $1 \mathrm{~mm}$ ，出力60W)在使用した。また， 測定データの処理は主にスペクトルダイナミック社の高 速フーリエ方式データ処埋装笝SD360型在使用した。 图 2 に微少温度变動測定用検出器の構造を示す。基板(ベ 一ク)上に線径 $0.02 \mathrm{~mm} 0 \mathrm{CA}$ 熱電対 30 対を直列に接続

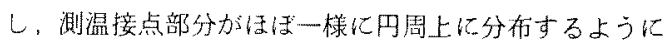
配㯰し，管路断面の平均温度ゆらぎ老検出できるように した。また測温接点部分は熱容量出来る限り少なくす るように特殊な溶接をした。CAサーモパイルの熱電能 は約 $1.24 \mathrm{mV} /{ }^{\circ} \mathrm{C}$ であり，周波数特性は直流から約 $20 \mathrm{~Hz}$ まで良好で古る。本奏験で主に使用した織物を表 1 に示 †े

\section{3. 実駼結果及び考察}

图 3 は $V=1 \mathrm{~m} / \mathrm{s}, \bar{\theta}=30^{\circ} \mathrm{C} と し ，(a)$ は管路に織物を 挿入しない場合で，(b)は管路に綿平織を摲入したとき にTP $P_{1}$ ŁT $P_{2}$ で得られた代表的な温度ゆらざ波形 $\theta_{1}(t)$

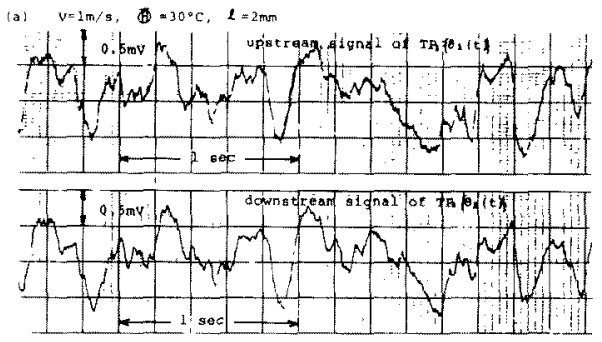

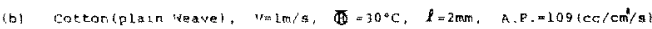

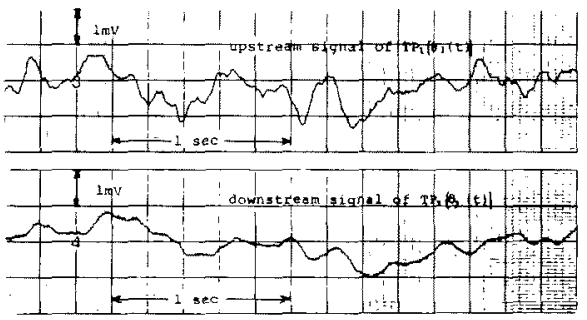

Fig. 3 Typical recordes of temperature fluctuation.

Table 1 Character of woven fabrics

\begin{tabular}{|c|c|c|c|c|c|c|c|c|}
\hline \multirow{2}{*}{$\begin{array}{l}\text { Sample } \\
\text { No. }\end{array}$} & \multirow{2}{*}{ Material } & \multirow{2}{*}{$\begin{array}{l}\text { Textile } \\
\text { Weave }\end{array}$} & \multicolumn{2}{|c|}{ Fineness (s) } & \multicolumn{2}{|c|}{ Threads Per cm } & \multirow{2}{*}{$\begin{array}{c}\text { Thickness } \\
\text { (mm) }\end{array}$} & \multirow{2}{*}{$\begin{array}{c}\text { Air Permeability } \\
\left(\mathrm{cc} / \mathrm{cm}^{2} / \mathrm{s}\right)\end{array}$} \\
\hline & & & Warp & Filling & Warp & Filling & & \\
\hline 1 & \multirow{3}{*}{ Cotton } & \multirow{3}{*}{$\begin{array}{l}\text { Plain } \\
\text { Weave }\end{array}$} & 40 & 20 & 36 & 15 & 0.37 & 160 \\
\hline 2 & & & 40 & 20 & 36 & 23 & 0.38 & 109 \\
\hline 3 & & & 40 & 20 & 36 & 27 & 0.38 & 30 \\
\hline 4 & \multirow{3}{*}{ Cotton } & \multirow{3}{*}{$\begin{array}{l}\text { Twill } \\
\text { Weave }\end{array}$} & 40 & 20 & 36 & 15 & 0.40 & 223 \\
\hline 5 & & & 40 & 20 & 36 & 23 & 0.42 & 174 \\
\hline 6 & & & 40 & 20 & 36 & 27 & 0.43 & 54 \\
\hline 7 & \multirow{3}{*}{ Cotton } & \multirow{3}{*}{$\begin{array}{l}\text { Satin } \\
\text { Weave }\end{array}$} & 40 & 20 & 36 & 15 & 0.48 & 295 \\
\hline 8 & & & 40 & 20 & 36 & 23 & 0.50 & 204 \\
\hline 9 & & & 40 & 20 & 36 & 27 & 0.60 & 89 \\
\hline
\end{tabular}




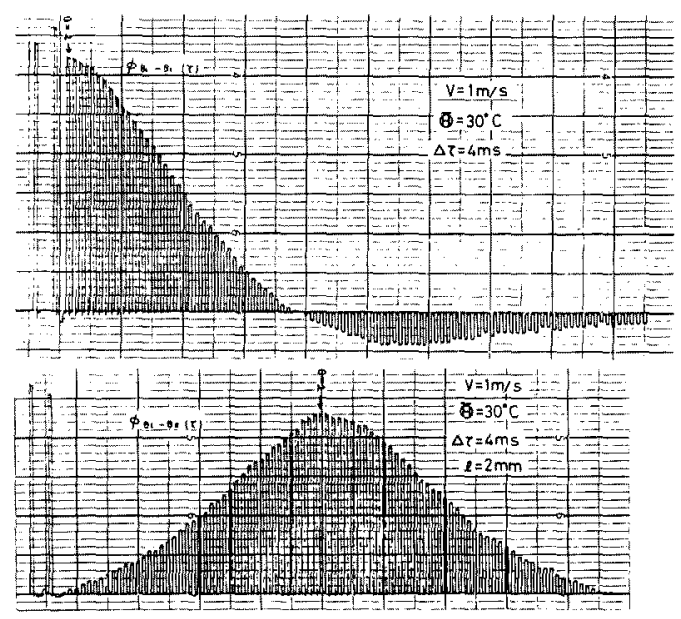

Fig. 4 Autocorrelation function and crosscorrelation function of temperature fluctuation.

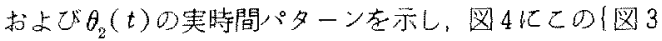
(a)) 自己相関関数 $\phi_{\theta_{1}-\theta_{1}}(\tau)$ 之相互相関関数 $\phi_{\theta_{1}-\theta_{2}}(\tau)$ を示す。 $\theta_{1}(t), \theta_{2}(t)$ は約 $20 \mathrm{~Hz}$ 以下o比较的低周波成 分考含んでいる。図3(a)では $\theta_{1}(t)$ と $\theta_{2}(t)$ はほぼ相似 であり，再者の有意な差が認められない。図3(b)では $\theta_{2}(t) 0$ 高周波成分が減衰し，全般的にパワーレベルが 低下している。図 5 , 図6に綿織物を管路内に挿入した 場合の温度伝達特性曲線を示す。横軸は周波数 $\omega の$ 対数 目盛をとり，䋖軸にゲィン(振幅減衰比) $g \mathrm{~dB}$ と位相 $\theta$ 度を示す。网 5 は $V=1 \mathrm{~m} / \mathrm{s}, \bar{\theta}=30^{\circ} \mathrm{C}$ と, 綿平織の 緯系密度のみを变化した場合であり，図 6 は $V=1 \mathrm{~m} / \mathrm{s}$, $\bar{\Theta}=30^{\circ} \mathrm{C}$, 経系と緯系の太さと経緯織密度を同一乙し， 織物組織を変化した場合である。織物は経禾上緯系の交 錯から出来て抢り，織り采が細く，織密度が小さいるの 程織物の糸相互間の間隍の集積が大きくなり，通気度

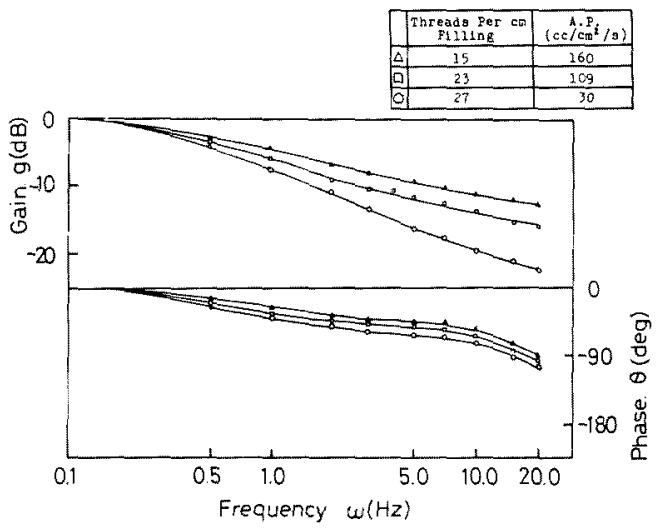

Fig. 5 Temperature transfer characteristics of cotton plain weave.

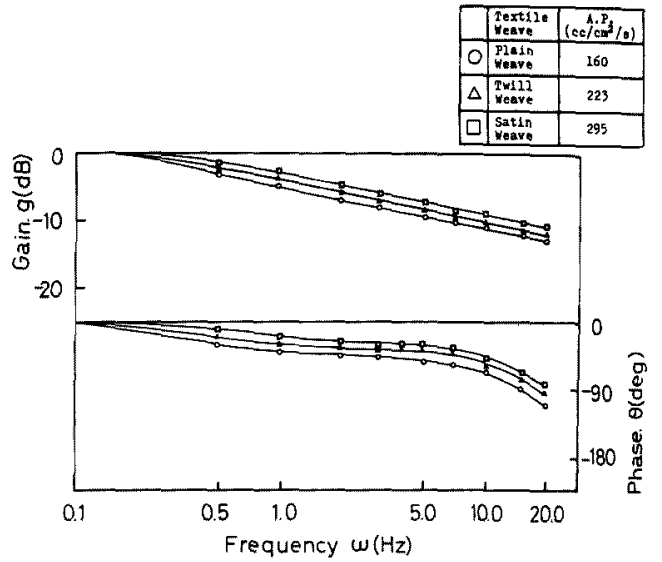

Fig. 6 Temperature transfer characteristics of three fundamental weaves.

(A，P.)加高くなる。織物の温度伝達特性は通気度の高 低により支配され，通気度の高い織物程ゲインレベルお よび位相遅れが小となり，織物を介して盜度が伝達され 易い屯の上考えられる。また，織物組織を变えた場合に は、朱子織が最むゲインレベルおよび位相遅れが小とな っている。てれは織物構造から考えて，朱子織が通過空 気に対する抵抗が鼠も小さく，通気度が高くなっている ため上思われる。戍 5 ，罒6亿示した織物の温度伝達特 性曲線加ら，織物のみ加けの温度伝達関数 $G(\mathrm{~s})$ を推定 すると，一次遅れ七むだ時間要素”を含んだ近似式 $G(s)$

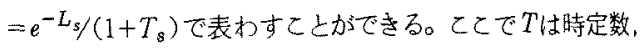
Lはむだ特間とする。すなわち，T拉よびLの各々の值が 小さい程ゲインレベルと位相遅れが小となり，温度が任達 され䀛い屯の上考えられる。また、TおよびLの值は平均 流速，織物の通铚度，厚さなどにより支配され，T扑 びLの各々の值の大小関係在求めることにより，動的な 場合の織物の温度伝達特性を評洒することができる。今 後，織物の材䨢，厚さなどの温度伝達特性に及ばす影響 謂心゙る必要があるう。

最俊に本研究を進めるにあたり，有养な助言を戴いた 東京大学豊田弘道教授並びに実駼に協力を戴いた塚越害 二君（現在松下電送K，K）に深く感謝いたします。

尚，本研究は著者の1人である鳥羽が研究代表者とな り，昭和 50 年 -53 年の 4 ケ年間文部省科学研究費の助 成によるものであり，こてに改めて韵意を表わします。

\section{文献}

1）たとえば，伸，鎌田；線熱源を利用する布の温度伝 導率上熱伝導率の测定，䋐維機械学会誌，26-2， 
70/75 (1973)

2）レイマンフォート他；被服機構学, 光生館, 115 (1972)

3）鳥羽，豊田，阿刀田；温度ゆらざを利用した気体の 流速測定，計測自動制䇴学会論文集，10-1，100/ $106(1974)$

4）鳥羽，塚越他；織物の通風性，保温性に関する一測 定方法(第2 報)，第 18 回自動制御連合講演会前别，
$549 / 550(1975)$

5）鳥羽，沢路他；織物の通風性保温性の測定，第19回 回自動制御連合講演会前刷，607/608 (1976)

6) 鳥羽，沃路他；織物の動的保温性の一測定，䌀維学 会年次大会予稿集，63(1977)

7）たとえば，秋山，鳥羽他：自動制湖演習，森北出版， $76 / 77$ (1972) 